\title{
MERENUNGKAN KEMBALI PERTANYAAN "SIAPAKAH SESAMAKU MANUSIA?"
}

\section{Sebuah Pengantar Editorial}

\author{
Adrianus Yosia \\ Wesley Theological Seminary \\ adrianus.yosia2305@gmail.com
}

Teologi publik dapat dimaknai sebagai suatu usaha dialogis dari komunitas Kristen dengan ragam kelompok di luar gereja untuk membahas isu-isu yang menjadi kepentingan bersama di ruang publik. ${ }^{1}$ Proses dialogis ini dapat dimulai dengan menggumulkan isu-isu yang ada pada suatu komunitas dengan konteks tertentu. Keluaran dari pergumulan dialogis ini adalah refleksi-refleksi teologis yang dapat menjawab isu-isu yang partikular dalam komunitas tersebut. Proses dialogis ini menjadi bagian dari perbincangan "tiga publik," yaitu gereja, masyarakat, dan akademi. ${ }^{2}$ Lebih jauh lagi, di dalam konteks inilah teologi, sebagaimana yang Jürgen Moltmann ujar, sejatinya selalu mempunyai wajah publik. ${ }^{3}$

Di dalam semangat dialogis berteologi publik ini, Indonesian Journal of Theology (IJT) mengangkat tema "Merenungkan Kembali Pertanyaan 'Siapakah Sesamaku Manusia?"' melalui edisi khusus ini. Pada edisi ini, sebagai keluaran dari proses dialogis yang terjadi, kami menawarkan lima artikel, diskusi buku Menolak Diam, dan juga satu resensi buku. Selain itu, ada juga satu resensi buku yang tidak terkait dengan tema. Dengan demikian, inilah sedikit sumbangsih dialog percakapan teologis yang ingin kami berikan di dalam diskursus teologi, baik di dunia, khususnya Asia, maupun di Indonesia. Namun, sebelum pembahasan mengenai artikel-artikel tersebut, ada baiknya alasan mengapa topik ini diangkat terlebih dahulu.

${ }^{1}$ Sebastian Kim, Theology in the Public Sphere: Public Theology as a Catalyst for Open Debate (Norwich: SCM Press, 2011), loc. 161.

${ }^{2}$ David Tracy, The Analogical Imagination: Christian Theology and the Culture of Pluralism (London: SCM Press, 1981).

3 Jürgen Moltmann, God for a Secular Society: The Public Relevance of Theology (Minneapolis, MN: Fortress Press, 2005), 5. 


\section{Siapakah Sesamaku Manusia?}

Apabila proses berteologi dimulai dengan suatu pertanyaan, tampaknya "siapakah sesamaku manusia?" menjadi salah satu pertanyaan penting yang bergaung di dalam enam bulan terakhir di Indonesia, terutama pada masa pandemik COVID-19. Bukan berarti bahwa pertanyaan ini merupakan satu-satunya pertanyaan penting yang ada di masyarakat, hanya saja pandemi ini ternyata memunculkan kejadian-kejadian yang dapat memicu pertanyaan tersebut. Akibatnya, pertanyaan "siapakah sesamaku manusia" dapat menjadi suatu konteks berteologi yang cukup menarik ataupun memicu refleksi teologis yang bertemakan pertanyaan tersebut. Minimal, ada tiga isu yang dapat menunjukkan bahwa pertanyaan tersebut merupakan pertanyaan penting pada pandemik ini.

Pertama, pada bulan Mei 2020 yang lalu, majalah TEMPO memberikan satu tajuk yang menarik, yakni "Para Pengisi Ruang Kosong." "Tajuk ini memberitakan mengenai tentang pelbagai kelompok yang menunjukkan solidaritas bagi golongan papa yang mengalami pukulan ekonomi yang sangat keras akibat pandemik COVID-19. Ketika situasi memburuk dan pemenuhan kebutuhan individu tak terpenuhi, besar kemungkinan manusia memilih posisi untuk "menjadi serigala bagi sesamanya" demi menyelamatkan diri dan keluarganya. Akan tetapi, artikel tersebut justru menunjukkan bahwa ada orang-orang yang justru semakin memikirkan kesejahteraan sesamanya dengan bertindak secara nyata untuk meringankan beban orang lain.

Masih terkait dengan sifat peduli dengan orang lain, pada jejak pendapat yang dilakukan oleh KOMPAS per tanggal 28 Agustus 2020, ada persepsi kuat di masyarakat tentang menguatnya rasa nasionalisme dan persatuan yang disebabkan, salah satunya, oleh "solidaritas antar-sesama warga yang dinilai cukup membaik" selama masa pandemi. ${ }^{5}$ Lewat jejak pendapat ini, ternyata sikap yang "kepedulian antar sesama manusia" di Indonesia selama berlangsungnya pandemi COVID-19 merupakan keadaan sosial yang cukup menjadi kenyataan publik di Indonesia. Memang jajak pendapat ataupun artikel tersebut tidak membahas motivasi dari kelompok pemberi bantuan, namun minimal tindakan mereka menunjukkan bahwa ada motif "siapakah sesamaku manusia?" yang diejawantahkan di dalam bentuk bantuan sosial. Dengan demikian, artikel dari majalah TEMPO dan juga jajak pendapat di KOMPAS ini memberikan suatu gambaran mengenai pergumulan

4 Wayan Agus Purnomo, "Para Pengisi Ruang Kosong," 16 Mei 2020, Tempo, diakses 1 September 2020, https://majalah.tempo.co/read/laporanutama/160481/solidaritas-publik-melawan-corona-tanpa-menunggu-negara. Agustus 2020 .

5 Yohan Wahyu, "Memperkuat Imunitas Kebangsaan," Kompas, 28 
"siapakah sesamaku manusia?" ini masih terus bergaung bahkan pada keadaan Indonesia masa kini.

Selanjutnya, cara hidup yang biasa dan dianggap "normal" dalam hal berelasi dengan manusia lainnya mengalami perombakan total pada masa pandemi. Perombakan pertama adalah penggunaan masker untuk meredam penyebaran wabah COVID-19 sebagaimana yang diusulkan oleh World Health Organization (WHO). ${ }^{6}$ Perombakan kedua adalah mode interaksi yang dianggap "santun" dan "beradab" dengan tetangga dan teman, seperti jabat tangan, pelukan, serta perkunjungan, juga mesti dibatasi demi kebaikan bersama komunitas. Perombakan ketiga adalah perubahan pertemuan-pertemuan fisik ke dalam dunia virtual demi mengakomodasi kebutuhan untuk berjalannya kehidupan seharihari dengan pencegahan pandemi.

Mengapa perombakan-perombakan sikap ini perlu dilakukan? Salah satu jawabannya adalah pencegahan penyebaran COVID-19. Selain bahaya dari COVID-19 yang mempunyai efek penularan yang sangat tinggi, perombakan-perombakan tersebut dapat membantu seseorang untuk menjaga kehidupan dari orangorang sekitar yang dikasihinya. Dengan demikian, salah satu motif yang dapat menjadi penggerak agar setiap orang mau melakukan perombakan-perombakan tersebut adalah jawaban atas pertanyaan "siapakah sesamaku manusia?" Karena aku ingin menjaga orangorang di sekitarku, kepedulian terhadap "sesamaku manusia" di sekitarku inilah yang membuatku ingin melakukan perombakanperombakan ini. Di dalam pengertian yang paling minimal ini, "siapakah sesamaku manusia?" menjadi sesuatu pertanyaan yang tanpa sadar direnungkan secara serius di dalam masa pandemi ini.

Ketiga, pandemi COVID-19 menyibak kerentanan dari pihak-pihak yang secara mudah termajinalkan di dalam kondisi ekonomi yang sulit, terutama perempuan, anak-anak dan juga komunitas yang terpinggirkan lainnya. ${ }^{7}$ Sebagai contoh lainnya, hasil survei dari Komnas Perempuan menyatakan bahwa 60\% responden perempuan yang mempunyai penghasilan di bawah lima juta rupiah per bulan rentan untuk mengalami kekerasan di dalam rumah tangga. ${ }^{8}$ Dengan demikian, perempuan pun menjadi pihak yang paling rentan di dalam keluarga. Di dalam konteks kerentanan

${ }^{6}$ World Health Organization, "Advice on the Use of Masks in the Context of COVID-19," June 5, 2020, accessed September 1, 2020, 1, https://apps.who.int/iris/rest/bitstreams/1279750/retrieve.

7 Gadis Arivia, "Feminisme Dan COVID-19," Jurnal Perempuan, 11 Mei 2020, diakses 7 September, 2020, https://www.jurnalperempuan.org/wacanafeminis/feminisme-dan-covid-19.

${ }^{8}$ Komnas Perempuan, "Siaran Pers \& Eksekutif Summary KAJIAN DINAMIKA PERUBAHAN DI DALAM RUMAH TANGGA (English Version)," July 28, 2020, accessed September 7, 2020, https://www.komnasperempuan.go.id/reads-siaran-pers-eksekutif-summarykajian-dinamika-perubahan-di-dalam-rumah-tangga-english-version. 
inilah Gadis Arivia mengajak pemerintah untuk memikirkan kaum yang termarjinalkan di dalam pembuatan kebijakan pada masa pandemic COVID-19.' Tentunya, ajakan untuk merangkul kaum yang terpinggirkan ini merupakan gema dari pertanyaan "siapakah sesamaku manusia" yang perlu diejawantahkan di dalam kebijakankebijakan pemerintah di dalam masa-masa pandemi COVID-19.

Tentu ada begitu banyak kasus-kasus lain ataupun pertanyaan-pertanyaan penting lainnya yang dapat diangkat semasa pandemi COVID-19. Namun, minimal ketiga isu ini dapat menggambarkan gaung dari pertanyaan "siapakah sesamaku manusia" yang menjadi isu krusial pada masa-masa pandemi ini. Lebih jauh lagi, gaung pertanyaan ini membuat setiap manusia pada masa-masa pandemi ini perlu menghidupi sekaligus merefleksikan kembali pemahaman mereka.

\section{Tulisan-tulisan dalam Edisi Ini}

Berangkat dari konteks dan pertanyaan "siapakah sesamaku manusia" inilah tulisan-tulisan di dalam edisi ini diangkat. Tentu, sebagai sebuah catatan yang penting, tulisan-tulisan yang terdapat di dalam edisi ini tidak semuanya membahas secara langsung tematema yang disebutkan di atas. Namun demikian, artikel-artikel yang kami pilih untuk dimuat menawarkan refleksi-refleksi teologis terkait pertanyaan "siapakah sesamaku manusia?" yang menjadi tema mendalam untuk dipikirkan.

Tulisan pertama dari Erwin Susanto mengetengahkan sebuah refleksi Kristen atas situasi penderitaan yang dialami umat manusia di masa pandemik COVID-19 ini melalui pembacaan atas Kitab Ayub dan buku "Sampar" (La Peste) karya Albert Camus. Susanto berargumentasi bahwa kedua buku tersebut sama-sama menangkal cara berpikir yang stabil tentang Allah dan karya-Nya terkait kenyataan penderitaan. Lebih dari itu, keduanya juga menggarisbawahi bahwa manusia perlu berperan aktif ketika berhadapan dengan penderitaan sebagai kenyataan yang dialami bersama manusia-manusia lainnya; ada dimensi relasional di balik penderitaan yang dialami.

Artikel kedua dari Leksmana Leonard menggemakan imajinasi "lapar akan Allah" dalam konteks teologi mistik dan juga transformasi sosial. Leonard melandaskan idenya pada tulisan Simone Weil yang menyatakan bahwa manusia sejatinya selalu mengalami mendamba Allah (baca: "lapar") dan secara kreatif menautkannya dengan trialog dari Dorothy Sölle. Sölle menyatakan bahwa spiritualitas mistik dimulai dari via positiva, via negativa, dan berujung kepada via transformativa. Dengan demikian, rasa lapar akan yang ilahi atau mendamba Allah selalu berujung kepada transformasi sosial. Kaitan dengan tema khusus dari IJT

\footnotetext{
9 Arivia, "Feminisme dan COVID-19."
} 
bulan ini adalah salah satu wujud dari menghidupi "siapakah sesamaku manusia" adalah rasa lapar spiritual yang berdampak kepada transformasi sosial di ruang publik.

Pada artikel ketiga, Irene Chrysantheme menggugat arti "siapa sesamaku manusia" di dalam konteks tata rias wajah perempuan. Chrysantheme mempertanyakan kembali standar kecantikan seorang perempuan yang biasanya diukur dengan penampilan fisik sehingga penggunaan tata rias tampak menjadi sebuah kebutuhan esensial. Keindahan seorang perempuan dinilai berdasarkan penampilan fisiknya. Lewat penelusuran psikologi dan juga teologi estetika dari Hans Urs von Balthasar, Chrysantheme mengusulkan bahwa manusia sejatinya indah pada dirinya sendiri, sebagai gambar dan rupa Allah. Dengan demikian, indah atau tidaknya seorang perempuan tidak ditentukan oleh tata rias wajah semata. Gugatan dari Chrysantheme kembali "memaksa" pembacanya untuk memikirkan ulang "siapakah sesamaku manusia?" dalam konteks standar kecantikan seorang perempuan.

Berikutnya, Irene Ludji menggunakan pemikiran "the acting person" dari Karol Wojtyla, atau yang lebih dikenal dengan Paus Yohanes Paulus II, untuk menganalisis relasi antara para pekerja kemanusiaan (bumanitarian workers) dengan para migran yang berada dalam situasi rentan di perbatasan Amerika Serikat dan Mexico di dalam artikelnya. Ia menganalisis secara krisis bagaimana relevansi pemikiran Wojtyla di dalam situasi kontemporer dan mengidentifikasi bagaimana solidaritas bersifat imperatif di antara sesama yang setara. Dengan demikian, para relasi antara pekerja kemanusiaan dan para migran yang dilayani juga direnungkan kembali. Ludji mengajak pembacanya untuk kembali memikirkan "siapakah sesamaku manusia" di dalam konteks para migran di Amerika Serikat dan Mexico.

Baiju Markose, di dalam artikel terakhir di edisi ini, menyatakan pentingnya mengembangkan praktik poskolonial yang mengaitkan misi Kristen dan gerakan lintas-iman sebagai bentuk perlawanan terhadap fundamentalisme agama dan kapitalisme berdasarkan kroni di India masa kini. Ia mengkritik bentuk-bentuk dialog antara-agama yang formalistik berdasarkan ide toleransi dan mengusulkan pentingnya kebersamaan dengan umat beragama lain sebagai bentuk komitmen kesaksian Kristen yang lebih hakiki. Walaupun tulisan ini ditulis di dalam konteks India, tulisan Markose juga memberikan wawasan atas permenungan kembali kembali "siapakah sesamaku manusia?" di Indonesia yang juga terus bergumul dengan pluralitas agama.

Sebagai bagian untuk menyuarakan suara yang termajinalkan dalam diskursus "siapakah sesamaku manusia," kami juga menyelenggarakan diskusi atas buku Menolak Diam: Gereja 
Melawan Perdagangan Orang. ${ }^{10}$ Buku ini secara spesifik membahas isu perdagangan manusia yang ada di Indonesia Timur dan bagaimana isu ini menjadi pergumulan bagi gereja lokal, terutama Gereja Masehi Injili di Timor (GMIT). Secara khusus kami meminta tiga orang penulis yang bukan warga jemaat GMIT untuk memberikan tanggapan terhadap isu tersebut.

Kami menyarankan agar pembaca dapat memulai pembacaan dari tulisan Danang Kurniawan yang dengan apik memberikan kesimpulan singkat dari buku Menolak Diam dan mengusulkan suatu cara pembacaan terhadap buku ini. Sebagai bagian dari diskusi ini, Linna Gunawan dan juga Fang-fang Chandra memberikan respons masing-masing terhadap buku ini. Dari sudut pandang pendeta jemaat, Gunawan memberikan tanggapan bahwa buku ini dapat memerikan pemahaman bagi pembaca untuk mewujudkan syalom Allah di dalam dunia. Dari sudut pandang seorang mahasiswi teologi, Fang-fFang memberikan pemahaman mengenai pentingnya diskursus ini di dalam percakapan teologis di Indonesia.

Lefrandy Praditya memberikan resensi buku Doing the Work of Comparative Theology yang dikarang oleh Veli-Mati Kärkkäinen. Di dalam konteks keindonesiaan yang mana agama memegang identitas yang penting dari diri seseorang, metode komparasi teologi merupakan salah satu hal yang penting sekali untuk digunakan sebagai bagian dari proses berteologi di Indonesia. Dengan demikian, berbicara "siapakah sesamaku manusia" di dalam konteks berteologi di Indonesia mau tidak mau memerlukan metode komparasi teologi di dalamnya. Praditya dengan apik memberikan resensi dari buku tersebut.

Terakhir, Calvin Wu memberikan resensi buku Logika: Sebuah Pendekatan yang Berpusat pada Allah Menuju Fondasi Pemikiran Barat karangan dari Vern Sheridan Poythress. Wu dengan cermat menjelaskan butir-butir pemikiran dari Poythress sambal memberikan tanggapan yang bernas terhadapnya. Walaupun resensi ini tidak terkait dengan tema "siapakah sesamaku manusia?" pada edisi ini, resensi buku dari Wu dapat memberikan sumbangsih dalam diskursus logika matematika, filsafat, dan juga teologi.

\section{Tentang Penulis}

Adrianus Yosia adalah Research Fellow di Indonesian Journal of Theology. Saat ini dia sedang melanjutkan studi magister di Wesley Theological Seminary, Washington, D.C., Amerika Serikat.

${ }^{10}$ Mery Kolimon, et. al., eds., Menolak Diam: Gereja Melawan Perdagangan Orang (Jakarta: BPK Gunung Mulia, 2018). 
7 Merenungkan Kembali Pertanyaan "Siapakah Sesamaku

Manusia?"

\section{Daftar Pustaka}

Arivia, Gadis. "Feminisme dan COVID-19." 11 Mei 2020. Jurnal Perempuan. Diakses 7 September, 2020. https://www.jurnalperempuan.org/wacanafeminis/feminisme-dan-covid-19.

Kim, Sebastian. Theology in the Public Sphere: Public Theology as a Catalyst for Open Debate. Norwich: SCM Press, 2011.

Kolimon, Mery, et. al., eds. Menolak Diam: Gereja Melawan Perdagangan Orang. Jakarta: BPK Gunung Mulia, 2018.

Komnas Perempuan. "Siaran Pers \& Eksekutif Summary KAJIAN DINAMIKA PERUBAHAN DI DALAM RUMAH TANGGA (English Version)." July 28, 2020. Accessed September 7, 2020. https://www.komnasperempuan.go.id/reads-siaran-perseksekutif-summary-kajian-dinamika-perubahan-di-dalamrumah-tangga-english-version.

Moltmann, Jürgen. God for a Secular Society: The Public Relevance of Theology. Minneapolis, MN: Fortress Press, 2005.

Purnomo, Wayan Agus. "Para Pengisi Ruang Kosong." 16 Mei 2020. Tempo. Diakses 1 September 2020. https://majalah.tempo.co/read/laporanutama/160481/solidaritas-publik-melawan-corona-tanpamenunggu-negara

Tracy, David. The Analogical Imagination: Christian Theology and the Culture of Pluralism. London: SCM Press, 1981.

Wahyu, Yohan. "Memperkuat Imunitas Kebangsaan." Kompas. Kompas, 28 Agustus 2020.

World Health Organization. "Advice on the Use of Masks in the Context of COVID-19." June 5, 2020. Accessed September 1 , 2020. https://apps.who.int/iris/rest/bitstreams/1279750/retrieve. 